\title{
Vitiligo ile Serum 25(OH) D Vitamini İlişkisi
}

\section{Association Between 25(OH) Vitamin D and Vitiligo}

\author{
Erdinç Terzi ${ }^{1^{*}}$ \\ ${ }^{1}$ İstanbul Gelişim Üniversitesi, Sağlık Bilimleri Yüksekokulu, Avcılar, İstanbul,Turkiye \\ e-mail: erdincterzi@yahoo.com \\ ORCID: 0000-0002-5507-7326 \\ *Sorumlu yazar/ Corresponding Author: Erdinç Terzi \\ Gönderim Tarihi / Received: 21.09.2020 \\ Kabul Tarihi / Accepted: 25.01.2021 \\ DOI: $10.34087 /$ cbusbed. 797721
}

\begin{abstract}
Giriş ve Amaç: Vitiligo hastalarında serum 25-hidroksivitamin D (25 (OH) D) seviyelerini incelemek ve sağlıklı bireylerden oluşan kontrol grubu ile karşılaştırarak serum $25(\mathrm{OH}) \mathrm{D}$ seviyeleri ile vitiligo arasında olası bir ilişki olup olmadığ 1 belirlemektir.

Gereç ve Yöntemler: Ekim 2017-Mart 2018 tarihleri arasında vitiligo tanısı konulan 45 hasta ve 83 sağlıklı birey çalışmaya alındı.Çalışma grubunun serum D vitamini düzeyleri yüksek performans likit kromatografi yöntemi ile değerlendirildi.Ayrıca serum paratiroid hormon kalsiyum, fosfor, alkalen fosfataz seviyeleri de incelendi.

Bulgular: Çalışmamıza 9-55 yaş(ort 28,22 $\pm 7,1$ ) arasındaki 45 hasta ve kontrol grubunda 18-58 yaş arası(ortalama: $34,38 \pm 7.3) 83$ sağlıklı birey katılmıştır.Vitiligolu hastalarda serum $25(\mathrm{OH})$ D seviyeleri ortalama $22,19 \mathrm{ng} / \mathrm{ml}$ $(8,42-80,1 \mathrm{ng} / \mathrm{ml})$ olarak belirlendi. Kontrol grubunda ise serum $25(\mathrm{OH}) \mathrm{D}$ seviyeleri ortalama 23,4 ng $/ \mathrm{ml}(3-69,2$ $\mathrm{ng} / \mathrm{ml}$ ) olarak belirlendi.. Her iki grup arasında serum D vitamini düzeyi arasında istatistiksel olarak anlamlı bir fark yoktu(p>0.05).
\end{abstract}

Sonuç: Bu sonuçlar 1şığında serum 25(OH) D vitamini ile vitiligo arasında herhangi bir ilişki bulunmamıştır.

Anahtar kelimeler: İlișki, Vitiligo, 25(OH) D vitamini

Abstract

Objective: To evaluate serum 25-hydroxyvitamin D (25 (OH) D) levels in vitiligo patients and to determine whether there is a possible relationship between serum $25(\mathrm{OH}) \mathrm{D}$ levels and vitiligo by comparing it with a control group of healthy individuals.

Materials and Methods: 45 patients and 83 healthy individuals diagnosed with vitiligo between October 2017 and March 2018 were included in the study. Serum vitamin D levels of the study group were evaluated by high performance liquid chromatography method. Serum parathyroid hormone calcium, phosphorus, alkaline phosphatase levels were also examined.

Results: 45 patients between 9-55 years old (mean $28.22 \pm 7.1)$ and 83 healthy individuals between 18-58 years old (mean: $34.38 \pm 7.3)$ in the control group participated in our study. Serum $25(\mathrm{OH}) \mathrm{D}$ levels were determined as an average of $22.19 \mathrm{ng} / \mathrm{ml}(8.42-80.1 \mathrm{ng} / \mathrm{ml})$ in patients with vitiligo. In the control group, serum $25(\mathrm{OH}) \mathrm{D}$ levels were determined to be $23.4 \mathrm{ng} / \mathrm{ml}(3-69.2 \mathrm{ng} / \mathrm{ml})$. There was no statistically significant difference between the serum vitamin $\mathrm{D}$ levels between the two groups $(\mathrm{p}>0.05)$.

Conclusion: In the light of these results, no relationship was found between vitiligo and serum $25(\mathrm{OH})$ vitamin $\mathrm{D}$.

Keywords: Relationship, Vitiligo, 25(OH) Vitamin D.

\section{Giriş}

Vitiligo, cildin edinilmiş lokalize veya generalize depigmentasyonu ile karakterize olan bir polijenik otoimmün hastalıktır[1].Vitiligo hastaların yaşam kalitesini ciddi şekilde azaltmaktadır.Vitiligonun kesin patogenezi tam olarak anlaşılamamıştır.Vitiligo oluşumu için genetik yatkınlık, nöral teori ve otoimmün hipotez gibi çeşitli hipotezler ortaya konulmuştur[1].Vitiligo bir otoimmun hastalıktır ve romatoid artrit,diabetes mellitus,multiple skleroz gibi birçok otoimmun hastalık düşük D vitamini seviyeleri ile ilişkilidir[2].D vitamini yağda eriyen steroid yapıdadır,deride 7dehidrokolesterolden sentez edilir veya besinlerle vitamin olarak alınır. Hem doğal hem de uyarlanabilir 
bağışıklık sistemlerinin normal işlevine aracılık etmede rolü vardır ve çoğu dokuda yaygın olarak dağıtılan D vitamini reseptörüne(VDR) bağlanarak biyolojik etkilerini gösterir. D vitamini, otoimmüniteyi tetikleyebilecek veya şiddetlendirebilecek süreçlerde rol oynamaktadır [3,4].Çeşitli çalışmalar, D vitamini seviyelerinin, multipl skleroz,lupus erimatozis,tip 1 diabetes mellitus ve romatoid artrit dahil olmak üzere bazı otoimmün hastalıkların insidansı ve / veya ciddiyeti ile ilişkili olduğunu bildirmektedir[5-8].Ayrıca topikal D vitamini analogları psoriazis ve vitiligo dahil kutanöz otoimmun hastalıkların tedavisinde etkilidir[9]. Çalışmamızın amacı vitiligolu hastalarda D vitamini durumunu değerlendirmekti. Coğrafi alanımızdaki D vitamini eksikliği yaygınlığının yüksek olması nedeniyle, sağlıklı bir kontrol grubundaki seviyeleri de değerlendirdik ve Ekim 2017 ile Mart 2018 arasındaki iki grubu karşılaştırdık. Mevsimsel değişikliklerin D vitamini seviyeleri üzerindeki etkisini en aza indirmek için çalışma sonbahar ve kış aylarında gerçekleştirilmiştir.

\section{Materyal ve Metot}

\subsection{Hastalar}

Bu çalışma, Ekim 2017-Mart 2018 tarihleri arasında İstinye Üniversitesi Liv Hastanesi , Dermatoloji Anabilim Dalında gerçekleştirilmiştir. Vitiligolu 45 hasta (29 erkek ve 14 kadın) ve 83 sağlıklı kontrol grubu (24 erkek, 45 kadın) retrospektif olarak incelendi. Oral D vitamini desteğine; majör kardiyovasküler, karaciğer, böbrek veya sindirim hastalığı olan; testten 1 ay önce vitiligo tedavisi veya laboratuvar testini yapmayı reddedenler çalışmaya alınmadılar. Bölümdeki hasta görüşmeleri sırasında cinsiyet, yaş, vitiligo başlangıç öyküsü, ana tutulum yeri, hastalığın süresi,ilerlemesi ve komorbid otoimmün hastalı öyküsü gibi hasta bilgileri kaydedildi.Bu çalışma İstanbul Gelişim üniversitesi klinik araştırmalar etik kurulu (2017- 16/138) tarafından onaylanmış ve Helsinki Deklerasyonuna uygun olarak gerçekleştirilmiştir. Araştırmaya katılan hastaların sözlü ve yazılı onamları alınmıştır.

\subsection{Laboratuar Analizleri}

25-hidroksivitamin D (25 (OH) D) , kalsiyum, fosfor, alkalin fosfataz (ALP) ve paratiroid hormonu (PTH) düzeylerini değerlendirdik. $25(\mathrm{OH}) \mathrm{D}$ vitamini düzeyleri $20 \mathrm{ng} / \mathrm{ml}$ den düşük ise eksik, 20-30 ng / $\mathrm{ml}$ arasında ise yetersiz ve $30 \mathrm{ng} / \mathrm{ml}$ den yüksek ise yeterli olarak değerlendirildi. Serum kalsiyum, fosfor ve ALP seviyeleri spektrofotometrik bir cihazla ölçülmüştür(Roche Integra 800).D vitamini yüksek performans likid kromatografi cihazı kullanılarak ölçüldü.Serum PTH seviyeleri kemilüminesans immünoanaliz cihazı (Siemens Centaur XP) ile ölçüldü.

\subsection{Istatistiksel Analiz}

Veri analizi SPSS , sürüm 11.5 (SPSS Inc., Chicago, Illinois, United States) programı ile gerçekleştirildi. Sürekli değişkenlerin normal veya normal olmayan dağılımları Shapiro Wilk testi ile belirlenmiştir. Gruplar arasındaki ortalama farklar Student t-testi kullanılarak karşılaştırılmış, aksi takdirde medyan değerlerin karşılaştırılmasında bağımsız grup sayısına göre MannWhitney U veya Kruskal-Wallis testleri kullanılmıştır. Kruskal-Wallis test istatistiklerinden p-değeri istatistiksel olarak anlamlı olduğunda, hangi grubun diğer gruptan farklı olduğunu belirlemek için Conover'in parametrik olmayan çoklu karşılaştırma testi kullanıld1.Kategorik veriler Pearson'un $\mathrm{x}^{2}$ testi veya Fisher's exact testi ile analiz edildi. Semptomların süresi ile D vitamini seviyeleri arasındaki ilişki derecesi düzeyleri Spearman'ın korelasyon analizi ile değerlendirildi. Olgu ve kontrol grupları arasında ayrım yapmak için en iyi belirleyiciyi saptamak amaciyla çoklu lojistik regresyon analizi uyguland. Her bağımsız değişken için olasılık oranı ve \%95 güven aralıkları da hesaplanmıştır. İstatistiksel olarak anlamlılık p değerinin $0.05^{\prime}$ in altında olması olarak belirlendi.

\section{Bulgular ve Tartışma \\ 3.1.Bulgular}

Çalışmaya 9-55 yaş aralığında (ort 28,22 $\pm 7,1) 45$ (25 erkek, 20 kadın)hasta dahil edildi.Kontrol grubunda 1858 yaş aralığında(ort $34,38 \pm 7,3) 83$ sağlıklı birey (28 erkek, 55 kadın) alındı. Hasta ve kontrol grubu arasında ortalama yaş açısından istatistiksel olarak anlamlı fark yoktu.(Tablo 1).

Vitiligo olan 45 hasta arasında, ailede vitiligo öyküsü yoktu.Hastaların 15 'ünde $(\% 33,3)$ Hashimoto tiroiditi öyküsü vardı. (Tablo 2). Vitiligo hastalarda serum 25 $(\mathrm{OH})$ D seviyeleri ortalama 22,19 ng / ml (8,42-80,1 ng / ml) olarak tespit edildi.. Hastaların \% 48,9'unde D vitamini eksikliği, \% 33,3'ünde D vitamini yetersizliği ve $\% 17,8$ 'inda yeterli D vitamini seviyesi vard1. Kontrol grubunda ise serum $25(\mathrm{OH}) \mathrm{D}$ seviyeleri ortalama 23,04 $\mathrm{ng} / \mathrm{ml}(3-69,2 \mathrm{ng} / \mathrm{ml})$ tespit edildi.Kontrol grubunda ise deneklerin \% 49,4'ünde D vitamini eksikliği,\% 25,3'ünde D vitamini yetersizliği ve \% 25,3'ünda yeterli D vitamini seviyesi vardı. Her iki grup arasında serum D vitamini düzeyi arasında istatistiksel olarak anlamlı bir fark yoktu( $p>0.05)$.Çalışma gruplarındaki kadın ve erkek oranı incelendiğinde, $25(\mathrm{OH}) \mathrm{D}$ düzeyinde istatistiksel olarak anlamlı bir fark yoktu( $\mathrm{p}>0.05)$.

$10 \mathrm{ng} / \mathrm{ml}$ seviyesinin altında serum $25(\mathrm{OH}) \mathrm{D}$ seviyeleri hastaların \%13,3'ünde ve kontrol grubunun \%13,3'unda gözlenmiştir.Her iki grup arasında istatistiksel olarak anlamlı bir fark yoktu ( $>>0.05)$. Hastalar ve kontrol grubu arasında kalsiyum, fosfor, ALP ve PTH düzeyleri açısından istatistiksel olarak anlamlı fark yoktu(p> 0.05 )(Table 2).

3.1 Tartışma

D vitamini kalsiyum homeostazının düzenlenmesinde,hem hücre büyümesinde ve farklılaşma, ayrıca bağışıklık sistemi düzenlemesinde önemli bir rol oynayan bir hormondur[4, 5]. Biyolojik etkilere dayanarak, normal $25(\mathrm{OH}) \mathrm{D}$ seviyesi $\geq 30 \mathrm{ng} /$ dl'dir. D vitamini eksikliği, D vitamininin diyet alımındaki farklılıklar, güneş 1şığına maruz kalma sürelerinin değişmesi veya takviyelerin kullanılması nedeniyle dünya çapında giderek daha fazla tanınmaktadır, D vitamini eksikliğinin yaygınlığı çeşitli popülasyonlarda farklı modeller göstermektedir[10]. 
Table 1.Hastaların ve kontrol grubunun demografik verileri.

\begin{tabular}{|c|c|c|c|}
\hline 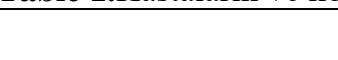 & Hasta Grubu & Kontrol Grubu & P değeri \\
\hline Yaş & $28,22 \pm 7,1$ & $34,38 \pm 7,3$ & 0,874 \\
\hline Cinsiyet & & & 0,487 \\
\hline Erkek & $25(\% 55,56)$ & $28(\% 33,7)$ & \\
\hline Kadın & $20(\% 44,44)$ & $55(\% 66,3)$ & \\
\hline Fitzpatrick Deri Tipi & & & 0,546 \\
\hline Tip 2 & $8(\% 17,8)$ & $13(\% 15,7)$ & \\
\hline Tip 3 & $26(\% 57,8)$ & $51(\% 61,4)$ & \\
\hline Tip 4 & $11(\% 24,4)$ & $19(\% 22,9)$ & \\
\hline Vitamin D(ng/ml) & $22,19(8,42-80,1)$ & $23,04(3-69,2)$ & 0,641 \\
\hline \multicolumn{4}{|l|}{ Vitamin D(ng/ml) } \\
\hline$>30$ & $8(\% 17,8)$ & $21(\% 25,3)$ & 0,805 \\
\hline $21-29$ & $15(\% 33,3)$ & $21(\% 25,3)$ & 0,484 \\
\hline$<20$ & $22(\% 48,9)$ & $41(\% 49,4)$ & 0,453 \\
\hline$<10$ & $6(\% 13,3)$ & $11(\% 13,3)$ & 0,432 \\
\hline Kalsiyum & $9,2 \pm 0,64$ & $9,3 \pm 0,59$ & 0,848 \\
\hline Fosfor & $3,6 \pm 0,57$ & $3,7 \pm 0,63$ & 0,731 \\
\hline ALP & $78,7 \pm 19,2$ & $74,3 \pm 16,7$ & 0,295 \\
\hline PTH & $62,6 \pm 18,9$ & $64,4 \pm 21,3$ & 0,340 \\
\hline
\end{tabular}

Tablo 2.Vitiligo hastaların klinik özellikleri

\begin{tabular}{|l|l|}
\hline Değişkenler & Sonuçlar \\
\hline Hastalık süresi(Ay) & \\
\hline$<1$ & $11(\% 25,6)$ \\
\hline $1-3$ & $11(\% 25,6)$ \\
\hline $4-6$ & $10(\% 23,2)$ \\
\hline$>6$ & $11(\% 25,6)$ \\
\hline Tutulum & \\
\hline Tek lezyon & $16(\% 37,2)$ \\
\hline Birden fazla lezyon & $27(\% 62,8)$ \\
\hline Otoimmun hastalık birlikteliği & $13(\% 30,2)$ \\
\hline Haşimato Troidit & $13(\% 30,2)$ \\
\hline Tip 1 Diabetes Mellitus & $2(\% 4,6)$ \\
\hline
\end{tabular}

Çeşitli çalışmalar, D vitamini seviyelerinin, tip 1 diyabetes mellitus, sistemik lupus eritematozus, multipl skleroz ve inflamatuar barsak hastalığı dahil olmak üzere bazı otoimmün bozuklukların insidansı ve / veya ciddiyeti ile ilişkili olduğunu bildirmektedir [5]. Son çalışmalarda, D vitamini eksikliğinin vitiligo oluşumu için önemli bir risk faktörü olabileceğini belirtilmiştir [7,11-13].

Sonuçlarımız vitiligo ve D vitamini eksikliği arasındaki ilişkiyi gösteren önceki raporlarla uyuşmamaktadır. Çalışmamızda hastaların $25(\mathrm{OH}) \mathrm{D}$ eksikliği olduğunu bulduk, ancak vitiligo hastaları ve sağlıklı kontroller arasında serum D vitamini düzeyleri açısından istatistiksel olarak anlamlı bir fark yoktu. $(p>0.05) . \mathrm{Bu}$, coğrafi alanımızda düşük $25(\mathrm{OH}) \mathrm{D}$ değerlerine yönelik eğilimden kaynaklanıyor olabilir. Hekimsoy ve ark., Türkiye'nin Ege bölgesinde yaptıkları populasyon temelli bir çalışmada yüksek bir D vitamini eksikliği (\% $74,9)$ ve yetersizliği $(\% 13,8)$ bulmuşlardır [14]. Türkiye'deki 1010 pediatrik hastada gerçekleştirilen araştırmada, Orun ve ark. $25(\mathrm{OH})$ D eksikliğinin (\%
24,3) ve yetersizliğinin çocuklukta, özellikle ergenlik döneminde s1k olduğunu göstermişlerdir[15]. Van der Meer ve arkadaşları, Türkiye nüfusunda D vitamini durumunun Türkiye'de güneş koruyucu kullanımına,diyette D vitamini alımının yetersiz olmasına, daha koyu ten rengine ve vücudun çoğunu kaplamak için kıyafet kullanma alışkanlığına göre çok değiştiğini göstermiştir [16].

D vitamini güneş 1şı ğ1 vitamini olarak bilinir. Bu vitaminin ana kaynağ $\mathrm{D}$ vitamininin derideki sentezidir. Çoğu insan için D vitamini ihtiyacının \% 90'ından fazlası gündelik güneş ışığına maruz ile karşılanmaktadır. D vitamininin doğal diyet kaynakları sinırlıdır [17]. Güneşli iklimlerde yaşayan orta doğu popülasyonlarında, özellikle Lübnan, İran, Ürdün ve Türkiye'den gelen yayınlarda D vitamini seviyelerinin çok düşük olduğu bildirilmiştir[18-20] . Bu durum, enlem, mevsimsellik, kirlilik, gümrük veya kültürel konular, diyet veya takviye edilmiş gıda politikaları gibi yaygın çevresel faktörlerden kaynaklanabilir. Ayrıca, bireysel giyim gibi sosyokültürel ve davranışsal faktörler, yüksek güneş 
koruma faktörü olan güneş kremlerinin kullanımı, güneşlenme alışkanlıkları, cilt pigmentasyonları, açık havada geçirilen zaman,ve yetersiz oyun alanları serum D vitamini seviyelerinin durumunu etkileyebilir.

\section{Sonuç}

Çalışmamızda hastaların $25(\mathrm{OH})$ D eksikliği olduğunu bulduk, ancak vitiligo hastaları ve sağlıklı kontroller arasında serum D vitamini düzeyleri açısından istatistiksel olarak anlamlı bir fark yoktu. $25(\mathrm{OH}) \mathrm{D}$ eksikliği ile vitiligo arasındaki ilişkiyi açıklığa kavuşturmak için daha fazla çalışmaya ihtiyaç vardır. Bize göre, vitiligo hastalarında kan $\mathrm{D}$ vitamini seviyelerinin taranmasını ve eksik olması durumunda vitiligo tedavi protokolüne oral $\mathrm{D}$ vitamini eklenmesini öneriyoruz.

\section{Referanslar}

1.Utas, S ,Sendur, N, Aydıngöz, I, et al., An epidemiologic study of Turkey: Vitiligo in childhood, Pediatric Dermatology, 2004, 21(3), 413.

2. Kriegel, M.A, Manson, J.E, Costenbader, K.H, Does vitamin D affect risk of developing autoimmune disease? A systematic review, Seminars in Arthritis Rheumatism, 2011, 40, 512-531.

3. Hewison, M, Vitamin D and the immune system: new perspectives on an old theme, Endocrinology Metabolism Clinics of North America, 2010, 39, 365-379.

4.LoPiccolo, M.C, Lim, H.W, Vitamin D in health and disease, Photodermatology Photoimmunology Photomedicine, 2010, 26 , 224-229.

5. Agmon-Levin, N, Shoenfeld, Y. Prediction and prevention of autoimmune skin disorder, Archives of Dermatological Research 2009, 301, 57-64.

6. Bergler-Czop, B, Brzezińska-Wcisło, L, Serum vitamin D level - the effect on the clinical course of psoriasis, Advances in Dermatology and Allergology, 2016, 33, 445-449.

7. Karagün, E, Ergin, C, Baysak, S, et al., The role of serum vitamin D levels in vitiligo, Advances in Dermatology and Allergology, 2016 $33,300-302$.

8. Kucharska, A, Szmurło, A, Sińska, B, Significance of diet in treated and untreated acne vulgaris, Advances in Dermatology and Allergology, 2016, 33, 81-86.

9. Amano, H, Abe, M, Ishikawa, O, First case report of topical tacalcitol for vitiligo repigmentation, Pediatric Dermatology, 2008, 25, 262264.

10. Lips, P, Hosking, D, Lippuner, K, et al, The prevalance of vitamin D inadequacy among women with osteoporosis: an international epidemiological investigation, Journal of Internal Medicine, 2006, $260,245-254$.

11. Saleh, H.M.A, Abdel Fattah, N.S.A, Hamza, H.T.M.M, Evaluation of serum 25-hydroxyvitamin D levels in vitiligo patients with and without autoimmune diseases, Photodermatology Photoimmunology Photomedicine, 2013, 29, 34-40.

12. Upala, S, Sanguankea, A, Low 25-hydroxyvitamin D levels are associated with vitiligo: a systematic review and meta-analysis, Photodermatology Photoimmunology Photomedicine, 2016, 32, 181190.

13. Zhang, J.Z, Wang, M, Ding, Y, Vitamin D receptor gene polymorphism, serum 25-hydroxyvitamin D levels, and risk of vitiligo:A meta-analysis, Medicine(Baltimore), 2018, 97, e11506.

14. Hekimsoy, Z, Dinç, G, Kafesçiler, S, et al., Vitamin D status among adults in the Aegean region of Turkey, BMC Public Health, 2010, 10, 782.

15. Orun, E, Sezer, S, Kanburoglu, M.K, et al., Vitamin D deficiency in healthy children and adolescent, Clinical and Investigative Medicine, 2015, 38, E261-266.

16. Van der Meer, I.M, Middelkoop, B.J, Boeke, A.J, Lips, P. Prevalence of vitamin D deficiency among Turkish, Moroccan, Indian and Sub-
Sahara African populations in Europe and their countries of origin: overview, Osteoporos International, 2011, 22, 1009-1021.

17. Holick, M.F, Sunlight and vitamin D for bone health and prevention of autoimmune diseases, cancers, and cardiovascular disease, American Journal of Clinical Nutrition, 2004, 80(6 Suppl), 1678S$88 \mathrm{~S}$.

18. Gannagé-Yared, M.H, Chemali, R, Yaacoub, N, et al. Hypovitaminosis D in a sunny country: relation to lifestyle and bone markers, Journal of Bone and Mineral Research, 2000, 15, 18561862

19. Mishal, A.A, Effects of different dress styles on vitamin D levels in healthy young Jordanian women, Osteoporos International, 2001, $12,931-935$.

20. Lips, P, Vitamin D status and nutrition in Europe and Asia, Journal of Steroid Biochemistry and Molecular Biology, 2007, 103, 620-625.

http://edergi.cbu.edu.tr/ojs/index.php/cbusbed isimli yazarın CBU-SBED başlıklı eseri bu Creative Commons Alınt1-Gayriticari4.0 Uluslararası Lisans1 ile lisanslanmıștır.

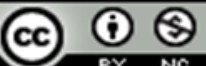

